TRENDS IN HYDROZOAN BIOLOGY - IV. C.E. MILLS, F. BOERO, A. MIGOTTO and J.M. GILI (eds.)

\title{
Approaches to the ethology of hydroids and medusae (Cnidaria, Hydrozoa)*
}

\author{
MARIA PIA MIGLIETTA ${ }^{1}$, LUIGI DELLA TOMMASA ${ }^{1}$, FRANCESCO DENITTO ${ }^{1}$, \\ CINZIA GRAVILI ${ }^{1}$, PATRIZIA PAGLIARA ${ }^{1}$, JEAN BOUILLON $^{2}$ \\ and FERDINANDO BOERO ${ }^{1}$
}

${ }^{1}$ Dipartimento di Biologia, Stazione di Biologia Marina, Museo dell’Ambiente, Università di Lecce, I-73100 Lecce, Italy.
2Laboratoire de Biologie Marine, Université Libre de Bruxelles, Ave F.D. Roosevelt 50, B-1050 Bruxelles, Belgique.

\begin{abstract}
SUMMARY: The behavioural patterns of 26 species of Antho- and Leptomedusae (with or without medusa stage) were investigated by video recordings. The analysed activities were: answers to mechanical stimuli, prey capture and ingestion, digestion, egestion, and swimming. The quantity of behavioural patterns identified in the small number of hydrozoan diversity studied so far is sufficient to demonstrate that these supposedly "simple" animals have evolved a complex array of responses to both external and internal stimuli.
\end{abstract}

Key words: Cnidaria, Hydrozoa, Anthomedusae, Leptomedusae, ethology, feeding.

\section{INTRODUCTION}

Cnidarians are the most primitive metazoans with complex behaviour. The other phyla with which they are placed at the root of the animal kingdom (i. e., Porifera, Placozoa and Mesozoa) have simple reactions to external stimuli only. Cnidarians, furthermore, have a well-developed nervous system and some have complex sense organs. They are, thus, the ideal group to investigate the origins of animal behaviour.

The nervous system of hydromedusae is more complex than the one of hydropolyps, being formed by a network of cells and fibres forming two rings connected by sparse fibres, one in the exumbrellar ectoderm and the other in the subumbrella. In some

*Received July 5, 1999. Accepted January 18, 2000. medusae, like Sarsia, the outer nervous ring passes at the base of tentacles, forming a tentacular ganglion that receives inputs from the ocelli. This probably serves as a centre for the directioning of nervous impulses between the tentacles and other body regions. Its role, thus, is that of a primitive and rudimentary brain (Mackie, 1971). Such medusan structures have no counterpart in hydroids, whose nervous system is a simple network. Both hydroids and medusae, however, answer a vast array of stimuli.

Hydroid feeding behaviour has not been studied much, although the first observations date back to the beginning of the 1900. Jennings (1906) was the first to describe as "feeding reaction" a behavioural pattern consisting in the movement of a hydranth after contact with a prey (tentacle retraction, mouth opening, etc.). Jennings (1906) stated that the feeding reaction is not a constant reflex, but depends on 
general physiological conditions, and reported on the importance of both mechanical and chemical stimuli. Many authors described the behaviour of single species, but without attempting a general classification of behavioural patterns. For instance, Vannucci (1956) observed that starved Dipurena hydranths move randomly in all directions while searching for a prey. Passano (1957) reported on the search movements of the hydranth of Corymorpha. Brinckmann-Voss (1970), followed by Edwards and Harvey (1983), studied the behaviour of the polymorphic colony of Thecocodium brieni. Orlov (1997) described the feeding behaviour of Sarsia producta.

Marfenin (1981) was the first to recognise the ecological importance of hydroid behaviour. He stated that every species, if examined in sufficient detail, has a unique feeding behaviour, this being determined, for instance, by the ability in prey capture, and by ingestion, digestion, and egestion times. Differences in these processes are related to environmental features, colony architecture, form and size of the hydranth and, if present, of the hydrotheca.

Medusae, being able to move in the water column, have more recognisable behavioural patterns than hydroids. Numerous authors, thus, studied medusan swimming and feeding behaviour. A common belief of past researchers (e. g., Hyman, 1940) was that medusae impact casually with their prey, so that both hydro- and scyphomedusae feed passively while swimming with their tentacles outstretched. If this were true, medusan-feeding efficiency would be simply related to tentacle number and length. Many recent observations on single species, however, led to a refined view of medusan behaviours. Mills (1981) and Costello (1988, 1992) distinguished ambush and cruising predators, relating foraging strategies to both tentacle morphology and arrangement and umbrella shape. Zamponi (1985) described an "alimentary space" and measured a "predation cylinder" from both tentacle number and length, and umbrellar diameter: a discrete volume of water in which a medusa can find a prey. Prey quality and quantity, furthermore, can induce varied foraging behaviours; physiological adaptations to low food availability are important aspects in hydromedusan ecology and account for the predatory efficiency of medusae (Costello, 1992). A particular case is that of the benthic and crawling medusae of Eleutheria, whose behaviour has been described in detail by Hadrys et al. (1990).
Valuable information on hydrozoan behaviour is scattered in literature on other topics. Behavioural data are present in many life cycle studies but are often mentioned neither in the abstract nor in the key words (e. g., Boero et al., 1991).

Most behavioural studies were centred on either polyps or medusae and the present paper is an attempt to identify general behavioural patterns for both stages from both Antho- and Leptomedusae, with or without a medusa stage.

\section{MATERIALS AND METHODS}

The behaviour of 18 species of Anthomedusae and 8 species of Leptomedusae was investigated (Table 1). Material was invariably sampled by collecting hydroids by SCUBA diving. Hydroids, fed with Artemia nauplii, were kept into hemispherical bowls, either attached to portions of their natural substrata or transplanted on microscopic slides. Hydroids were monitored seasonally in the field to identify fertile periods, and were collected and brought to the laboratory only when medusae were near to be liberated. Medusae were also kept into hemispherical bowls and fed with Artemia nauplii. Food was provided daily and water was changed after every feeding session. Both hydroids and medusae were kept in natural seawater filtered at $0.45 \mu \mathrm{m}$. The bowls were kept into thermostatic rooms having both temperature and photoperiod matching natural conditions. The behavioural patterns were studied under a Leica MZ12 stereomicroscope equipped with a videocamera and every pattern was recorded on videotape. Reaction to mechanical stimuli, capture of prey, ingestion, digestion, and egestion were investigated for both hydroids and medusae; swimming patterns were studied for medusae.

\section{RESULTS}

The observed behavioural patterns differed in the examined species, but it was possible to identify types of behaviour that are usually present in more than one species (Table 1). Although polyps and medusae constitute a single biological unit, they will be considered separately since their behaviours fall into different categories even within the same species. 
TABLE 1. - Behavioural patterns of polyps and medusae (see text for further explanation and references).

\begin{tabular}{|c|c|c|c|c|c|}
\hline \multirow{2}{*}{ Species } & \multirow[b]{2}{*}{ Mechanical stimuli } & \multicolumn{2}{|l|}{ Polyp } & \multicolumn{2}{|c|}{ Medusa } \\
\hline & & Prey capture & Digestion & Swimming & Prey capture \\
\hline \multicolumn{6}{|l|}{ Anthomedusae } \\
\hline \multicolumn{6}{|l|}{ Filifera } \\
\hline Bougainvillia sp. & Escape & Passive & Decrease of feeding space & Move & Mouth to tentacle \\
\hline Turritopsis nutricula & Escape & Passive & Decrease of feeding space & Move & Mouth to tentacle \\
\hline Eudendrium spp. & Escape & Passive & Inhibition of capture ability & Absent & Absent \\
\hline Hydractinia sp. & Escape & Passive & Decrease of feeding space & Absent & Absent \\
\hline Thecocodium brieni & Approach & Passive & Decrease of feeding space & Absent & Absent \\
\hline Amphinema dinema & $\begin{array}{l}\text { Unidirectional } \\
\text { bending }\end{array}$ & Passive & Decrease of feeding space & Move & Mouth to tentacle \\
\hline Codonorchis octaedrus & Escape & Passive & Decrease of feeding space & Move & Mouth \\
\hline Octotiara russelli & $\begin{array}{c}\text { Unidirectional } \\
\text { bending }\end{array}$ & Passive & Not seen & Not seen & Mouth \\
\hline Stomotoca atra & $\begin{array}{l}\text { Unidirectional } \\
\text { bending }\end{array}$ & Passive & Not seen & Not seen & Mouth \\
\hline \multirow{2}{*}{\multicolumn{6}{|c|}{ Capitata }} \\
\hline & & & & & \\
\hline Cladonema radiatum & Approach & Active & Decrease of feeding space & Move and catch & Tentacle to mouth \\
\hline Coryne producta & Approach & Active & Decrease of feeding space & Absent & Absent \\
\hline Dipurena halterata & Approach & Random & Decrease of feeding space & Not seen & Not seen \\
\hline Eleutheria dichotoma & Approach & Passive & Decrease of feeding space & Crawling & Tentacle to mouth \\
\hline Ectopleura wrighti & Approach & Passive & Inhibition of ingestion ability & Not seen & Mouth to tentacle \\
\hline Cladocoryne floccosa & Approach & Passive & Decrease of feeding space & Absent & Absent \\
\hline Zanclea sessilis & Approach & Passive & Decrease of feeding space & Move & Mouth to tentacle \\
\hline Zanclea giancarloi & Approach & Passive & Decrease of feeding space & Move & Mouth to tentacle \\
\hline \multicolumn{6}{|l|}{ Leptomedusae } \\
\hline Aequorea forskalea & Escape & Passive & Decrease of feeding space & Catch & Not seen \\
\hline Mitrocoma annae & Escape & Passive & Decrease of feeding space & Not seen & Not seen \\
\hline Campalecium medusiferum & $\begin{array}{l}\text { Unidirectional } \\
\text { bending }\end{array}$ & Passive & Decrease of feeding space & Move (young) & Mouth to tentacle \\
\hline Halecium pusillum & Escape & Passive & Not seen & Absent & Absent \\
\hline Aglaophenia octodonta & Escape & Passive/Active & Inhibition of capture ability & Absent & Absent \\
\hline Plumularia setacea & Escape & Passive & Inhibition of capture ability & Absent & Absent \\
\hline Clytia linearis & Escape & Passive & Decsease of feeding space & Catch & Mouth to tentacle \\
\hline Obelia dichotoma & Escape & Passive & Inhibition of capture ability & Catch & Mouth to tentacle \\
\hline
\end{tabular}

\section{Hydroids}

\section{Mechanical stimuli}

Single hydranths were stimulated mechanically with forceps, so to simulate harsh contact with a source of "disturbance". The behavioural responses fell within three categories: escape, approach, unidirectional bending.

Escape reactions (Fig. 1). Escape reactions were typical of the hydranths of filiferans and most thecates. They were classifiable in three patterns according to both morphological constraints and the intensity of the stimulus:

1 - tentacle contraction. Light stimuli usually caused tentacle contraction accompanied by tentacle folding towards the mouth. Halecium pusillum was the only species that folded the tentacles towards the column.

2 - hydranth contraction. Strong stimuli, or reiterated light stimuli, caused tentacle contraction and, simultaneously, hydranth contraction. In the species with a theca, this behaviour resulted in retraction into it. Well-fed hydranths of Aequorea forskalea and Mitrocoma annae, however, were not able to contract into their thecae and remained outside them even when contracted. The haleciids, having a reduced theca, resembled filiferans in this behavioural pattern.

3 - tentacle folding. Eudendrium spp. were not able to contract neither tentacles nor hydranth; disturbed hydranths folded their uncontracted tentacles around the peduncled hypostome.

Approach reactions (Fig. 1). All Capitata, and the dactylozooids of the filiferan Thecocodium brieni, bent their polyps towards the source of the mechanical stimulus, whatever its intensity. These species have short, capitate tentacles that are only slightly contractile. This active movement was related to the way these species catch their prey (see below).

Unidirectional bending (Fig. 1). The hydranths of some pandeids and of the thecate Campalecium medusiferum, when touched, bent in a constant 

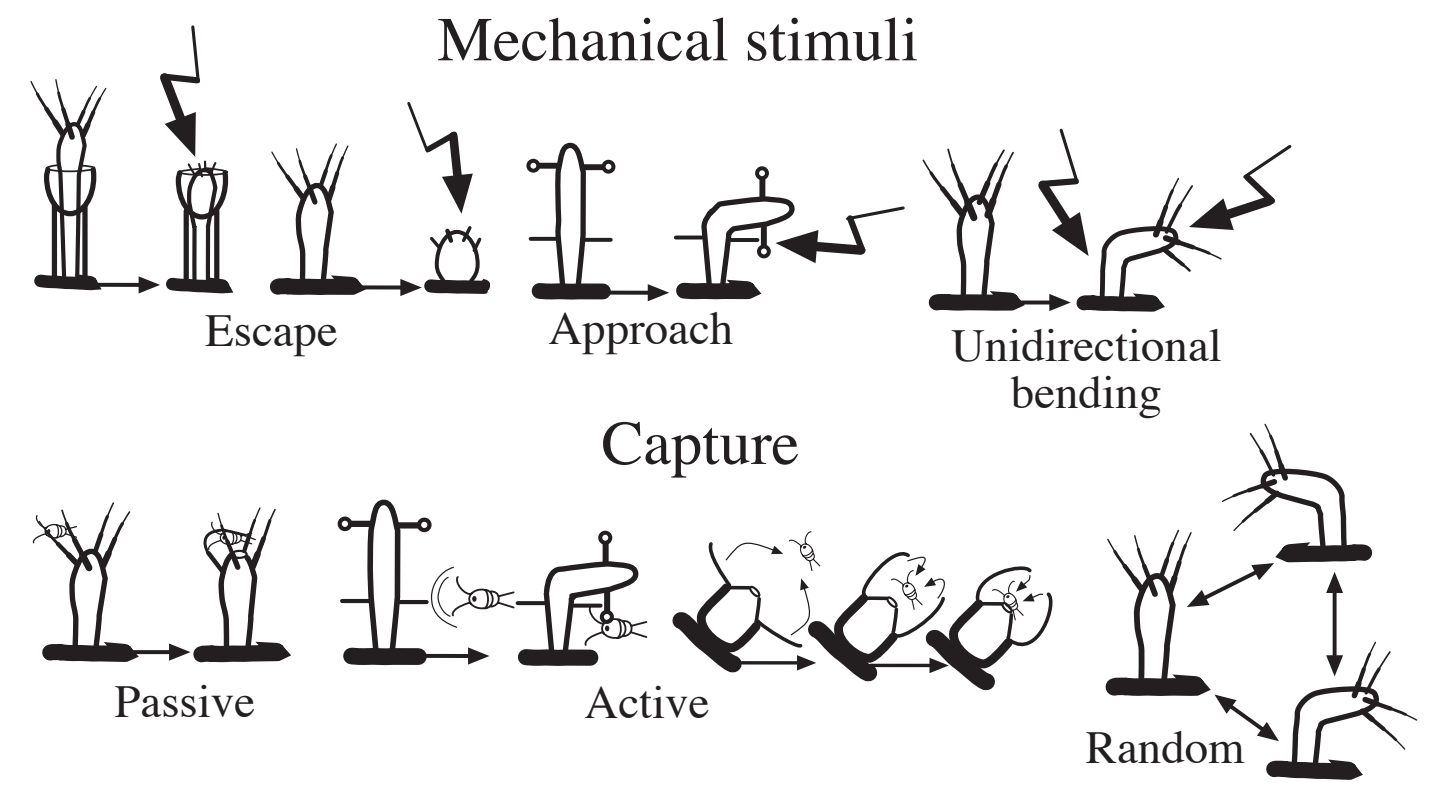

Behaviour during digestion $\times$

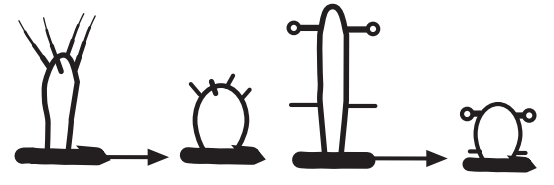

Decrease of feeding space

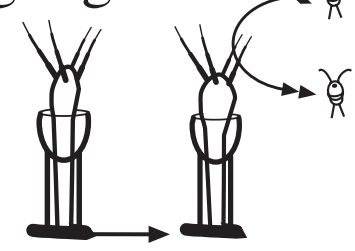

Inhibition of capture

\section{Behaviour during egestion}

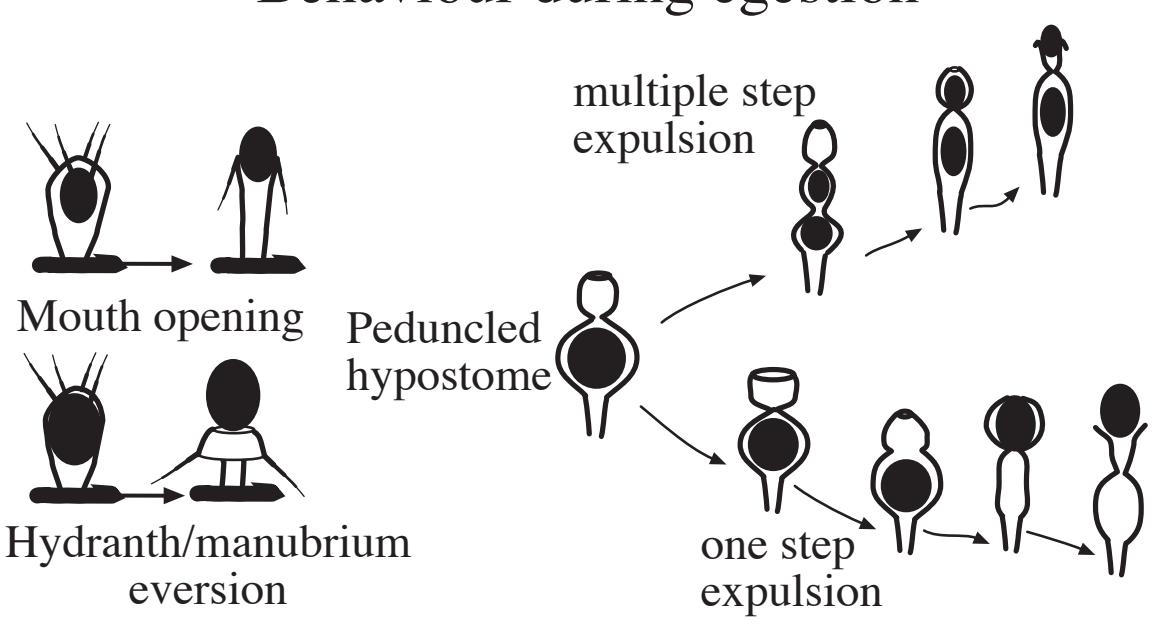

FIG. 1. - Answer to mechanichal stimuli, capture and behavior during digestion in hydroids; behavior during egestion in hydroids and medusae.

direction, irrespective of the direction of the stimulus. The hydranth, furthermore, bent at a welldefined place in its column; this allows to hypothesise the presence of a muscular "articulation" functioning as a knee or elbow. The histology of this region is not known in detail.

\section{Feeding patterns}

All feeding patterns were observed while using Artemia nauplii as food source. None of the investigated species will ever encounter such prey in the wild and it is known that hydroids do not feed on 
crustaceans only (Barangé, 1988; Barangé and Gili, 1988; Coma et al., 1995; Gili et al., 1996). It is presumed, however, that the feeding behavioural patterns remain rather constant whatever the offered food is. The observed feeding patterns fell into three categories:

Passive (Fig. 1). This was the typical capture strategy of hydranth with long and usually filiform tentacles extended in the water, defining a wide feeding space. They wait for the prey to collide with tentacles after having entered their feeding space. This feeding strategy was observed in most of the investigated species.

Thecocodium brieni had a peculiar passiveactive behaviour. The prey was passively captured by the dactylozooids. The gastrozooids, then, took it actively from the dactylozooids (see BrinckmannVoss, 1970 and Edwards and Harvey, 1983 for detailed descriptions).

Active (Fig. 1). The active strategy occurred typically in hydranths with mechanoreceptors (Tardent and Schmid, 1972); these were able to feel an approaching prey, bent actively towards it and caught it with their tentacles. The hydranths performing this behaviour usually had short capitate tentacles, but their ability to "move" around the stalk led to the control of a hemispherical feeding space.

Another active feeding pattern was that of the hydranth of Aglaophenia octodonta whose relatively long and filiform tentacles beat the surrounding water creating a flow that conveyed little prey or organic matter towards the hypostome.

Random (Fig. 1). This behaviour was typical of Dipurena halterata, whose hydranths bent randomly in all directions exploring a hemispherical space, from which they captured every passing prey. The hydranth of $D$. halterata can also feel water vibrations and bend towards the source. Unfed polyps bent continuously to increase the probability to contact a prey, but the swinging frequency decreased in fed hydranths. In the latter case, hydranths bent only when excited by a swimming prey.

\section{Behaviour during digestion}

The main function of hydranths was to capture prey with their tentacles and nematocysts and to ingest it. Once the coelenteron was full, the captured food that would have remained unused would have been a waste of both energy and nematoblasts. Two main behavioural patterns were observed during prey digestion:

Decrease of feeding space. Full hydranths without mechanoreceptors tend to contract their body and tentacles, so to minimise the feeding space. This structural modification was particularly evident in small hydranths like Codonorchis octaedrus which, during digestion, became so small to nearly disappear against the substrate (Boero et al., 1997).

Mechanoreceptors, when present, shrunk to little buttons. This lowered the sensitivity to water movement and hydranths did not bend toward approaching prey.

Inhibition of capture (Fig. 1) or of ingestion. Some hydranths did not capture any prey during digestion, even if their tentacles remained extended in the water. This suggests that nematocyst discharge is under some kind of control (Burnett et al., 1960; Clark and Cook, 1986; Grosvenor and KassSimon, 1987), being prevented when the enteron is full. This inertia, however, could also be the answer to a temporary lack of nematocysts after many captures.

Well-fed hydranths of Ectopleura wrighti did not ingest prey and did not move. The long aboral tentacles, however, continued to catch prey and kept it until the coelenteron was at least partly empty. Prey items, then, were picked up, one by one, by the oral tentacles.

\section{Medusae}

The number of observations for medusae was lower than for hydroids since many of the investigated species had no medusae. For some species with medusae, furthermore, it was impossible to observe behavioural patterns due to rearing difficulties. Hydranth growth is rapid and there are no distinct stages, although tentacle number increases in the growing athecate hydranths, possibly influencing their possibilities of prey capture. Medusae, instead, usually change much more than hydranths during growth. The medusae of both Clytia and Sarsia, for instance, are almost round at release, whereas they become respectively more flat or more elongate at later growth stages. The velar opening of newly released medusae is usually small and jet propulsion is intense. Larger medusae often have much wider velar openings and their propulsion is 
possibly due to flapping (Costello and Ford, in press). These changes surely influence behavioural patterns. In the present paper, we report mainly on fully-grown medusae.

\section{Swimming behaviour}

Swimming to move (Fig. 2). This behavioural pattern corresponds to the ambush predation described by Mills (1981). Medusae swam only to change the foraging site and prey. They remained still in either a horizontal (Codonorchis, Amphinema) or vertical position (Bougainvillia, Zanclea, Turritopsis and Campalecium), or while resting on the bottom (Cladonema).

Swimming to catch (Fig. 2). This behaviour corresponds to that of cruising predators (Mills, 1981). Medusae move actively in the water column searching for prey. Capture occurs when the prey contacts the tentacles. Capture rates depend on swimming velocity, prey type and predator morphological characteristics (Mills, 1981; Costello, 1988; 1992). Cladonema medusae can catch prey also while swimming as described by Rees (1979) but also can remain anchored to the bottom for a long time, so falling in the preceding category.

Crawling (Fig. 2). The medusae are anchored to the bottom with adhesive tentacular pads, and prey is captured with the tentacles. The change of foraging site occurs by walking on the bottom with the tentacles. This behaviour was observed by Hadrys $e t$ al. (1990) in Eleutheria dichotoma.

\section{Prey capture and ingestion}

Prey capture occurs with two main patterns:

With tentacles (Fig. 2). Two patterns of prey ingestion were recorded:

1 - Mouth to tentacle. Tentacles captured the prey and brought it to the subumbrellar margin by a fast retraction. After this, the manubrium moved out of the subumbrellar cavity to picked up the prey. Crumpling was a particular case of mouth-totentacle reactions: the umbrella contracted, pushed the manubrium out the velar opening, and the mouth ingested the prey. In Obelia dichotoma preys were killed by mouth nematocysts but were the continuous tentacle movement that brought them towards the mouth. This active filter feeding was similar to the one reported for the hydranths of Aglaophenia octodonta. Boero and Sarà (1987) described the same behaviour for the medusae of Obelia longissima.

2 - Tentacle to mouth. Captured preys are brought actively to the mouth by the tentacles. In Cladonema radiatum, prey items were forced into the subumbrellar cavity by the motile and branched marginal tentacles that passed them to the oral tentacles which passed them to the mouth. In Eleutheria dichotoma the casual contact of tentacles with a prey during crawling induced active tentacle movement towards the mouth, allowing prey ingestion.

With mouth (Fig. 2). Some species captured preys with their lips and not with their tentacles. Stomotoca atra and Octotiara russelli belong to this category (Boero and Bouillon, 1989). Hydrichthis mirus anchored one or two tentacles to the bottom, then it swam away while remaining attached, so stretching the attached tentacles for a rather long distance. Subsequent contraction of the attached tentacles caused a rapid backward movement of the umbrella, during which preys entered the subumbrellar cavity and contacted with the oral lips (Boero et al., 1991).

Codonorchis octaedrus used its lips to capture prey that entered by chance in its subumbrellar cavity (Boero et al., 1997).

\section{Egestion in hydroids and medusae (Fig. 1)}

Undigested food remains were eliminated during egestion, allowing further uptake of food. Hydroids and medusae had similar egestion behaviours (performed by hydranths and manubria respectively), and this section covers both stages. The elimination of small amounts of waste occurred by contraction of manubrial/hypostomial walls, resulting in pushing undigested material towards the mouth, which was then opened to allow egestion. The oral tentacles, when present, were turned downwards in hydranths and upwards in medusae. When waste was more abundant, this behaviour was often followed by a turning inside-out of the distal part of the hydranth/manubrium, so that the digestive wall was at least partly exposed. This behaviour was commonly observed in medusae, during crumpling, but was not observed in the hydranths of the observed species of Turritopsis, Halecium, and Plumularia.

The hydranths of the Campanulariidae had particular egestion patterns, linked to the presence of a separation between the hypostomic and the gastric 


\section{Capture behaviour}
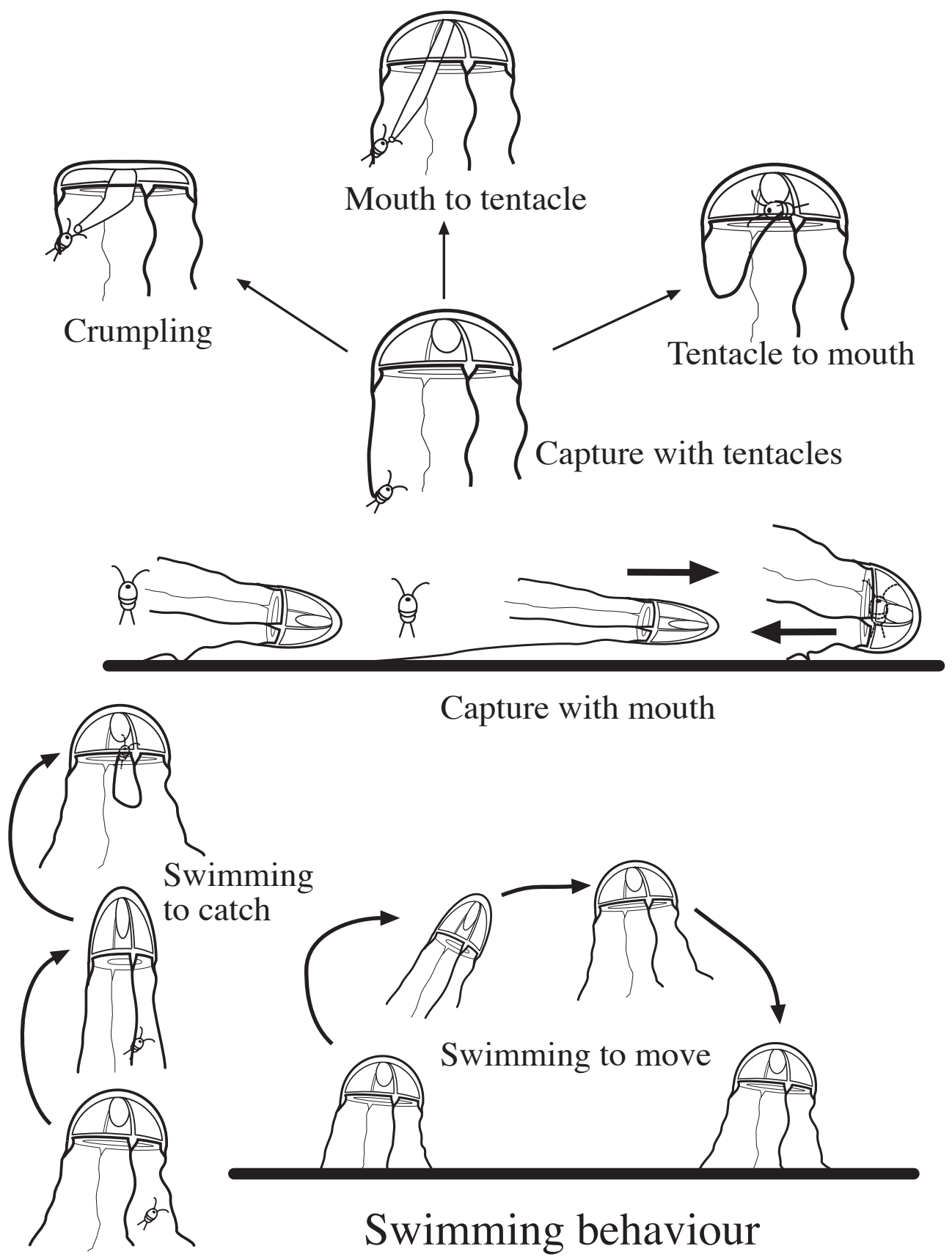

Capture with mouth
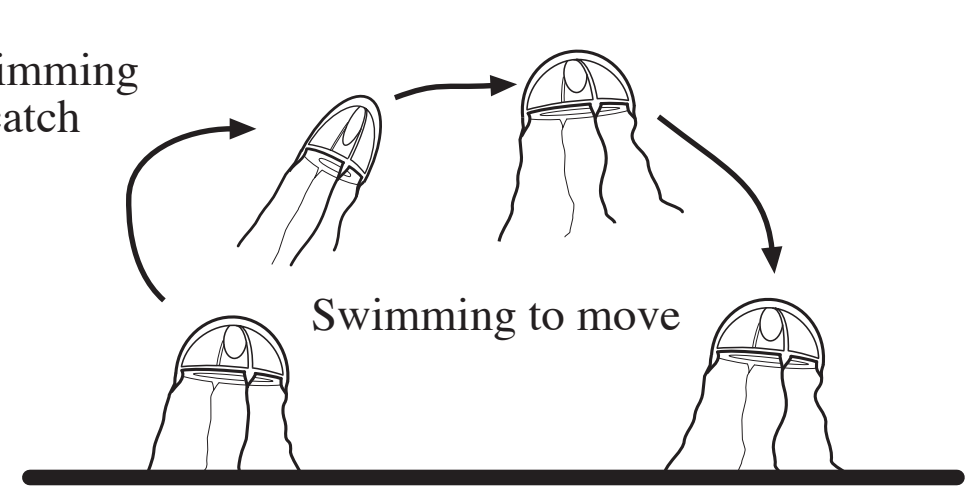

\section{Swimming behaviour}

FIG. 2. - Capture and feeding behavior in medusae.

cavity, resulting in the so-called peduncled or trumpet-shaped hypostome. This constriction acted as a sphincter that played a paramount role in the functioning of the hydranth cavity. Three main ways of functioning of peduncled hypostomes were recognised:

1 - Multiple steps expulsion of egesta. Part of the undigested material was passed towards the hypos- tome while the sphincter was open. The sphincter contracted, causing fragmentation of the egesta, part of the egesta remained in the hydranth coelenteron, part in the hypostome. The mouth was opened and the constriction of the hypostome walls caused egestion. The expulsion of the rest of the egesta occurred in further steps, identical to the first one. This behaviour was observed in Clytia linearis. 
2 - One step expulsion of egesta. The mouth was opened while the sphincter was closed, allowing the entrance of water into the hypostome. The mouth was closed and the sphincter was opened, the hypostome walls were contracted, pushing water into the hydranth coelenteron. The incoming water pushed up the egesta while the hydranth walls contracted; the egesta were passed into the hypostome. The sphincter contracted, separating the hypostome from the hydranth coelenteron; the mouth was opened, allowing waste elimination. This behaviour was observed in Obelia.

3 - Hypostome eversion. In Eudendrium waste was pushed up in the hypostome through the sphincter, but then it was egested by the turning inside out of the distal part of the hydranth.

\section{DISCUSSION}

The feeding patterns of capitate hydroids depend on tentacle number and on presence/absence of mechanoreceptors. Passive predators have a high number of tentacles controlling a wide feeding space in order not to fail the capture of a prey passing in their vicinity (e. g., Zanclea). Active predators (e. g., Cladonema, Sarsia, Coryne) have mechanoreceptors sensitive to prey movement. Their feeding space is wide due to the possibility of hydranth bending towards approaching prey, so that even a low number of tentacles are sufficient to kill an already located food item.

The feeding behaviour of Dipurena halterata is intermediate between passive (without mechanoreceptors and many tentacles) and active (with mechanoreceptors and few tentacles) patterns, with random bending movements, increasing the feeding space. Dipurena halterata has fewer tentacles than Zanclea (passive predator) but more than Sarsia or Coryne (active predators).

Most thecates are passive predators. Aglaophenia octodonta is exceptional since its active feeding pattern is not performed by using mechanoreceptors, and might be labelled as "random active". The water flow caused by beating tentacles suggests that some species of hydroids, always considered as passive filter feeders, can behave like active (but not ciliary) filter feeders such as barnacles.

Mechanoreceptors are known in some Capitata only and they possibly evolved only once. Unidirectional bending as a response to mechanical stimuli, but irrespective of their direction, on the other hand, was observed in both athecates (many Pandeidae species) and thecates (Campalecium medusiferum). The presence of the same behaviour in such different groups suggests convergent evolution that led to a still uninvestigated flexible zone.

The behaviour of medusae ranges from "classical" patterns of prey capture, to others such as the active filter feeding of Obelia (described by Boero and Sarà, 1987) or the yo-yo tentacle contraction of Hydrichthys (described by Boero et al., 1991). A world apart is the behaviour of symbiotic hydroids such as Halocoryne (described by Piraino et al., 1991) and Eugymnanthea inquilina (described by Piraino et al., 1994), reaching extremely high levels of complexity and specialisation.

Scattered unpublished observation, furthermore, suggest that the behavioural patterns of both hydroids and medusae are even more diverse than presented here and that the available observations cover just a minor part of hydrozoan ethology. Both ethology and behavioural ecology focused much on "higher" invertebrates and vertebrates but the available evidence suggests that even "lower" groups can perform behaviours of high complexity.

\section{ACKNOWLEDGEMENTS}

Work done with contributions of M.U.R.S.T. (40 and $60 \%$ programmes), C.N.R. (PRISMA 2 Project), the Amministrazione Provinciale di Lecce, N.S.F. (P.E.E.T.) and of the F.N.R.S. de Belgique.

\section{REFERENCES}

Barangé, M. - 1988. Prey selection and capture strategies of the benthic hydroid Eudendrium racemosum. Mar. Ecol. Prog. Ser. 47: 83-88.

Barangé, M. and J.M. Gili. - 1988. Feeding cycles and prey capture in Eudendrium racemosum (Cavolini, 1785). J. Exp. Mar. Biol. Ecol., 115: 281-293.

Boero, F. and J. Bouillon. - 1989. The life cycles of Octotiara russelli and Stomotoca atra (Cnidaria, Anthomedusae, Pandeida). Zool. Scr., 18 (1): 1-7.

Boero, F., J. Bouillon and C. Gravili. - 1991. The life cycle of Hydrichthis mirus (Cnidaria: Hydrozoa: Anthomedusae: Pandeidae). Zool. J. Linn. Soc., 101: 189-199.

Boero, F., C. Gravili, F. Denitto, M.P. Miglietta and J. Bouillon. 1997. The rediscovery of Codonorchis octaedrus (Hydroidomedusae, Anthomedusae, Pandeidae), with an update of the Mediterranean hydroidomedusan biodiversity. Ital. J. Zool., 64: 359-365.

Boero, F. and M. Sarà. - 1987. Motile sexual stages and evolution of Leptomedusae (Cnidaria). Boll. Zool., 54 (2): 131-139.

Brinckmann-Voss, A. - 1970. Anthomedusae/Athecata (Hydrozoa, Cnidaria) of the Mediterranean. Part I. Capitata. Fauna e Flora Golfo di Napoli, 39: 1-96.

Burnett, A.L., T. Lentz and M. Warren. - 1960. The nematocyst of Hydra (Part I). The question of control of the nematocyst dis- 
charge reaction by fully fed Hydra. Annls Soc. r. zool. Belg., 90: 247-267.

Clark, S.D. and C.B. Cook. - 1986. Inhibition of nematocyst discharge during feeding in the colonial hydroid Halocordyle disticha (=Pennaria tiarella): the role of previous prey-killing. Biol. Bull. mar. biol. Lab. Woods Hole, 171: 405-416.

Coma, R., J.M. Gili and M. Zabala. - 1995. Trophic ecology of a benthic marine hydroid, Campanularia everta. Mar. Ecol. Prog. Ser., 119: 211-220.

Costello, J.H. - 1988. Laboratory culture and feeding of the hydromedusa Cladonema californicum Hyman (Anthomedusa: Cladonemidae). J. exp. mar. Biol. Ecol., 123: 177-188.

Costello, J.H. - 1992. Foraging mode and energetics of hydrozoan medusae. In: J. Bouillon, F. Boero, F. Cicogna, J.M. Gili and R.G. Hughes (eds): Aspects of Hydrozoan biology, Sci. Mar., 56: 185-191.

Costello, J.H. and M.D. Ford. - in press. Comparison of oblate and prolate medusan propulsion: do oblate medusae use jet propulsion? Sci. Mar.

Edwards, C. and S.M. Harvey. - 1983. Observations on the hydroids Coryne pintneri and Thecocodium brieni new to the British list. J. mar. biol. Ass. U.K., 63: 37-43.

Gili, J.M., R.G. Hughes and V. Alvà. - 1996. A quantitative study of feeding by the hydroid Tubularia larynx Ellis and Solander, 1786. Sci. Mar., 60 (1): 43-54.

Grosvenor, W. and G. Kass-Simon. - 1996. Feeding behaviour in Hydra. I. Effects of Artemia homogenate on nematocyst discharge. Biol. Bull. mar. biol. Lab. Woods Hole, 173: 527-538.

Hadrys, H., B. Schierwater and W. Mrowka. - 1990. The feeding behaviour of a semi-sessile hydromedusa and how it is affected by the mode of reproduction. Anim. Behav., 40: 935-944.

Hyman, L.H. - 1940. Observations and experiments on the physiology of medusae. Biol. Bull. mar. biol. Lab. Woods Hole, 79: 282-296.

Jennings, H.S. - 1906. Behavior of the lower organisms. Chapter XI - Introduction and behavior of Coelenterata. Columbia Univ. Press, N.Y.: 188-232.
Mackie, G.O. - 1971. Neurological complexity in medusae: a report of central nervous organization in Sarsia. In: Actas I. Simposio int. Zoofilogenia. Acta salmant. (Cienc.), 36: 269-280.

Marfenin, N.N. - 1981. Nekotorye osobennosti pishchevareniya $\mathrm{v}$ gidrantakh u razlichnykh kolonial'nykh gidroidov. Some observations of the nutrition and the digestive process in hydranths of different colonial hydroids. Zh. obshch. Biol., 42: 399-408.

Mills, C.E. - 1981. Diversity of swimming behaviors in hydromedusae as related to feeding and utilization of space. Mar. Biol., Berl., 64: 185-189.

Orlov, D. - 1997. Observations on the White Sea hydroid, Sarsia producta (Wright, 1858) (Hydrozoa: Athecata). Sarsia, 81: 329-338.

Passano, L.M. - 1957. Prey-predator recognition in the lower Invertebrates. In: B. Scheer (ed.): Recent Advances in invertebrates physiology, pp. 37-49.

Piraino, S., J. Bouillon and F. Boero. - 1992. Halocoryne epizoica (Cnidaria, Hydrozoa), a hydroid that 'bites'. In: J. Bouillon, F. Boero, F. Cicogna, J.M. Gili and R.G. Hughes (eds.), Aspects of Hydrozoan Biology, Sci. Mar., 56: 141-147.

Piraino, S., C. Todaro, S. Geraci and F. Boero. - 1994. Ecology of the bivalve-inhabiting hydroid Eugymnanthea inquilina in the coastal sounds of Taranto (Ionian Sea, SE Italy). Mar. Biol., 118 (4): 695-703.

Rees, J.T. - 1979. The polyp and immature stages of Cladonema californicum Hyman, 1957 (Anthomedusae: Cladonemidae) with biological notes and a discussion of the taxonomy of the genus Cladonema. J. nat. Hist. 13: 295-302.

Tardent, P. and V. Schmid. - 1972. Ultrastructure of mechanoreceptors of the polyp Coryne pintneri (Hydrozoa, Athecata). Exp. Cell Res., 72: 265-275.

Vannucci, M. - 1956. Biological notes and description of new species of Dipurena (Hydrozoa, Corynidae). Proc. Zool. Soc. Lond., 127: 479-487.

Zamponi, M.O. - 1985. La alimentación de algunas especies de Hydromedusae. Neotrópica, 31: 155-162. 